Eur. J. Clin. Chem. Clin. Biochem.

Vol. 29, 1991, pp. 787-794

(C) 1991 Walter de Gruyter \& Co. Berlin - New York

\title{
The Establishment and Evaluation
}

\section{of Luminescent-Labelled Immunometric Assays for Prostate-Specific Antigen- $\alpha_{1}$-Antichymotrypsin Complexes in Serum}

\author{
By W. G. Wood ${ }^{1}$, Esther van der Sloot ${ }^{1}$ and A. Böhle ${ }^{2}$ \\ ${ }^{1}$ Klinische Laboratorien, Klinik für Innere Medizin \\ ${ }^{2}$ Klinik für Urologie \\ Medizinische Universität zu Lübeck, Lübeck, Federal Republic of Germany
}

(Received April 4/August 27, 1991)

Summary: Prostate-specific antigen is found in the prostate in two forms, one with a low $(30000)$ and one with a high (100000) relative molecular mass. The latter has recently been found to be a complex of prostatespecific antigen with $\alpha_{1}$-antichymotrypsin.

Immunoluminometric assays were designed for the prostate-specific antigen- $\alpha_{1}$-antichymotrypsin complex as well as for $\alpha_{1}$-antichymotrypsin, the former being compared with a commercially available radioimmunoassay for prostate-specific antigen (ProsChek RIA - Yang Laboratories).

The precision of the immunoluminometric assays was acceptable (intra-assay variation $<7 \%$; inter-assay variation $<8.5 \%$ ) in the measuring ranges $0-90 \mu \mathrm{g} / 1$ for the prostate-specific antigen- $\alpha_{1}$-antichymotrypsin complex and $0-12 \mathrm{~g} / 1$ for $\alpha_{1}$-antichymotrypsin.

The correlation between the assays for prostate-specific antigen and prostate-specific antigen- $\alpha_{1}$-antichymotrypsin complex was acceptable, showing a correlation coefficient $r=0.83$ after double logarithmic transformation, or $\mathrm{r}=0.85$ using the Spearman rank correlation on 131 data pairs.

Extremely high $\alpha_{1}$-antichymotrypsin levels (above $2 \mathrm{~g} / \mathrm{l}$ ) caused interference in the prostate-specific antigen$\alpha_{1}$-antichymotrypsin complex assay. Such levels, although rare, are encountered in pulmonary inflammatory disease.

The reference ranges for the three assays were found to be as follows:

prostate-specific antigen $0.13-4.63 \mu \mathrm{g} / \mathrm{l}$, prostate-specific antigen- $\alpha_{1}$-antichymotrypsin complex $0.08-1.78 \mu \mathrm{g} / \mathrm{l}$, and for $\alpha_{1}$-antichymotrypsin $0.27-0.61 \mathrm{~g} / 1$.

These values were obtained from 82 hospitalised males for the first two assays and from 80 males and females free from infection for the latter.

Purified prostate-specific antigen $\left(M_{\mathrm{r}} 30000\right)$ does not react in the prostate-specific antigen- $\alpha_{1}$-antichymotrypsin complex assay; a concentration of $200 \mu \mathrm{g} / 1$ generates a signal which is less than that from the first standard $(0.04 \mu \mathrm{g} / 1)$.

In three cases of metästatic cancer of the prostate, discrepancies were found in the values from the prostatespecific antigen assay $(8.56,30.0$ and $107 \mu \mathrm{g} / \mathrm{l})$ and the prostate-specific antigen- $\alpha_{1}$-antichymotrypsin complex assay $(0.78,3.72$ and $1.24 \mu \mathrm{g} / \mathrm{l})$. This may indicate the production of an altered prostate-specific antigen, which was unable to complex with $\dot{\alpha}_{1}$-antichymotrypsin.

The new assay is not suitable as a screening assay for prostatic cancer, but it may be of interest for detecting metastatic disease. 


\section{Introduction}

The determination of serum prostate-specific antigen $(1,2)$ has been shown to be a better diagnostic indicator than tartrate-inhibited or prostate-specific acid phosphatase $(3,4)$. Although prostate-specific antigen has a better diagnostic sensitivity and specificity than its predecessors, it is unsuitable for screening for prostatic cancer (7), because many patients with benign disease of the prostate show elevated values in assays using this antigen $(5,6)$.

Since prostate-specific antigen is complexed with $\alpha_{1-}$ antichymotrypsin (8), most probably to neutralise the protease activity of prostate-specific antigen (9) (analogous to the formation of elastase- $\alpha_{1}$-antitrypsin complexes in serum (10)), an assay was established to measure prostate-specific antigen- $\alpha_{1}$-antichymotrypsin complexes in serum.

The assay was compared with a classical radioimmunoassay for prostate-specific antigen (11), as well as with an immunoluminometric assay for serum $\alpha_{1-}$ antichymotrypsin. The latter assay was used to test for the possible influence of high native $\alpha_{1}$-antichymotrypsin concentrations in falsifying the results of the prostate-specific antigen- $\alpha_{1}$-antichymotrypsin complex assays.

\section{Materials and Methods}

Antibodies to prostate-specific antigen were obtained from DAKO (Hamburg, Germany).

Antibodies to $\alpha_{1}$-antichymotrypsin were purchased from DAKO and Atlantic Antibodies (Baxter, Munich, Germany).

Polystyrene balls for the solid phase $(6.4 \mathrm{~mm}$ diameter) were ordered from Spherotech Kugeln (Fulda, Germany).

Streptavidin was purchased from Calbiochem-Behring (Frankfurt a.M., Germany), and amidocaproylbiotin-N-hydroxysuccinimide ester from Sigma (Deisenhofen, Germany).

The luminescent label, 9-(4-succinimidobutyl-N-ethyl) aminobenzo (f) phthalazine-1, $4(2 \mathrm{H}, 3 \mathrm{H})$ dione (ABEN-H), was synthesised according to Schroeder et al. (12) and was coupled to antibodies after synthesis of its $\mathrm{N}$-hydroxysuccinimide ester (13).

The radioimmunoassay kit used for comparison was the prostate-specific antigen (ProsChek RIA) from Yang Laboratories (IBL, Hamburg, Germany). Standards for the prostate-specific antigen- $\alpha_{1}$-antichymotrypsin complex assay. were calibrated in terms of the prostate-specific antigen content in both the Yang RIA and Hybritech prostate-specific antigen-immunoradiometric assay.

The $\alpha_{1}$-antichymotrypsin standard serum was obtained from Behringwerke (Marburg a.d. L., Germany), (Code No. OUCL 06/07).

Radioactivity was counted in an automatic gamma spectrometer (LKB 1277 Gammamaster) with on-line PC (Pharmacia, Freiburg, Germany). Luminescence was measured in a 250 sample semiautomatic luminometer LB 952-16T - (EG \& G Berthold, Wildbad, Germany).
The assay schemes for prostate-specific antigen, $\alpha_{1}$-antichymotrypsin and prostate-specific antigen- $\alpha_{1}$-antichymotrypsin complex are shown in tables $1 \mathrm{a}-1 \mathrm{c}$.

For establishment of reference ranges and to check for specificity ("paraneoplastic-prostate-specific antigen" production in other tumours), samples were obtained from healthy volunteers and patients attending the urology clinic, as well as patients with renal insufficiency, lung cancer and other benign, nonprostatic diseases. Data from 270 patients were studied during the evaluation period.

\section{Statistics}

Statistics were carried out using non-parametric tests. The Mann-Whitney U-Test was used for independent variables, the Wilcoxon signed rank test for paired data and the Spearman rank test for regression analysis. The data distribution was checked with the Kolmogorov Smirnoff test at the level $\alpha=0.05$.

Tab. 1. Assay schemes for prostate-specific antigen, $\alpha_{1}$-antichymotrypsin and prostate-specific antigen- $\alpha_{1}$-antichymotrypsin complexes

a) Prostate-specific antigen radioimmunoassay - Yang laboratories (ProsChek PSA-RIA)

$200 \mu \mathrm{l}$ standard/sample

$200 \mu \mathrm{l}^{125} \mathrm{I}$-labelled prostate-specific antigen

$200 \mu$ l Anti-prostate-specific antigen

Incubate overnight at ambient temperature $500 \mu \mathrm{l}$ Precipitating antibody/pölyethylene glycol

Incubate $15 \mathrm{~min}$ at $2000 \mathrm{~g}$

Decant supernatant

Count precipitate for $1 \mathrm{~min}$

b) $\alpha_{1}$-antichymotrypsin immunoluminometric assay

$10 \mu \mathrm{l}$ standard or sample (1:1000 dilution)

$200 \mu l$ assay buffer

1 Anti $\alpha_{1}$-antichymotrypsin-coated ball (DAKO)

Incubate $60 \mathrm{~min}$ at ambient temperature and $170 \mathrm{~min}^{-1}$

Wash with $2 \times 5 \mathrm{ml}$ aqua bidest

$200 \mu \mathrm{l} \mathrm{ABEN-labelled} \mathrm{anti} \alpha_{1}$-antichymotrypsin

Incubate and wash as above, transfer ball to fresh cuvette, pipette $300 \mu \mathrm{l}$ catalase, load luminometer, inject $300 \mu \mathrm{l}$ $\mathrm{NaOH} / \mathrm{H}_{2} \mathrm{O}_{2}$

Integrate light signal for $2 \mathrm{~s}$

c) Prostate-specific antigen- $\alpha_{1}$-antichymotrypsin complex immunoluminometric assay

$50 \mu \mathrm{l} \mathrm{sample} /$ standard

$200 \mu$ assay/buffer

1 Anti prostate-specific antigen-coated ball (DAKO) .

Incubate for $90 \mathrm{~min}$ at ambient temperature and $170 \mathrm{~min}^{-1}$ Wash with $4 \times 5 \mathrm{ml}$ aqua bidest

$200 \mu \mathrm{l}$ biotin-labelled anti $\alpha_{1}$-antichymotrypsin

Incubate and wash as above

$200 \mu l$ streptavidin-ABEN

Incubate $30 \mathrm{~min}$, wash as above, and proceed as in b) above

Integrate light signal over $2 \mathrm{~s}$

Ranges covered by the standard curves for each assay

Prostate-specific antigen $\quad 0-50 \mu \mathrm{g} / \mathrm{l}$

$\alpha_{1}$-Antichymotrypsin $\quad 0-12.4 \mathrm{~g} / 1$

.Prostate-specific antigen- $\alpha_{1}$-antichymo- $\quad 0-90 \mu \mathrm{g} / 1$ trypsin complex 


\section{Experiments and Results}

\section{Establishment of reference ranges}

The prostate-specific antigen radioimmunoassay was carried out according to the manufacturer's instructions using the overnight incubation at room temperature.

Tab. 2. Quality control data for all 3 assays

a) Prostate-specific antigen radioimmunoassay (Yang Laboratories)

Precision profile data

\begin{tabular}{lll} 
Range $(\mu \mathrm{g} / \mathrm{l})$ & Mean CV $(\%)$ & No. of data pairs \\
\hline $2-5$ & 6.24 & 114 \\
$5-20$ & 3.97 & 63 \\
$20-50$ & 4.13 & 41
\end{tabular}

Inter-assay precision*)

\begin{tabular}{lll} 
Serum & $\begin{array}{l}\text { Mean concentra- } \\
\text { tion }(\mu \mathrm{g} / \mathrm{l})\end{array}$ & $\mathrm{CV}(\%)$ \\
\hline $\mathrm{K} 1$ & 2.64 & 9.52 \\
$\mathrm{~K} 2$ & 10.1 & 6.73 \\
$\mathrm{~K} 3$ & 41.2 & 7.51
\end{tabular}

b) Prostate-specific antigen- $\alpha_{-}$-antichymotrypsin

Precision profile data

\begin{tabular}{clc} 
Range $(\mu \mathrm{g} / \mathrm{l})$ & Mean CV $(\%)$ & No. of data pairs \\
\hline $0.2-2.0$ & 5.17 & 225 \\
$2.0-10.0$ & 4.32 & 104 \\
$10.0-90.0$ & 4.19 & 58
\end{tabular}

Inter-assay precision

\begin{tabular}{lll} 
Serum & $\begin{array}{l}\text { Mean concentra- } \\
\text { tion }(\mu \mathrm{g} / \mathrm{l})\end{array}$ & $\mathrm{CV}(\%)$ \\
\hline $\mathrm{K} 1$ & 0.73 & 8.82 \\
$\mathrm{~K} 2$ & 3.65 & 6.77 \\
$\mathrm{~K} 3$ & 20.4 & 6.39
\end{tabular}

c) $\alpha_{l}$-Antichymotrypsin

Precision profile data

\begin{tabular}{llc} 
Range $(\mathrm{g} / \mathrm{l})$ & Mean CV (\%) & No. of data pairs \\
\hline $0.05-0.3$ & 6.85 & 79 \\
$0.3-0.7$ & 4.22 & 188 \\
$0.7-4.0$ & 3.92 & 56
\end{tabular}

Inter-assay precision

\begin{tabular}{lll} 
Serum & $\begin{array}{l}\text { Mean concentra- } \\
\text { tion }(\mathrm{g} / \mathrm{l})\end{array}$ & $\mathrm{CV}(\%)$ \\
\hline K1 & 0.21 & 8.44 \\
K4 & 0.55 & 7.21 \\
K5 & 1.29 & 6.97 \\
\hline
\end{tabular}

*) Inter-assay precision was determined in each case in 20 consectutive assays from the means of duplicate determinations.
The reference ranges ( $95 \%$ confidence limits) established in 82 hospitalised male patients with non-prostate diseases and without bacterial infections were $0.13-4.63 \mu \mathrm{g} / 1$ (median 1.60) for prostate-specific antigen, and $0.08-1.78 \mu \mathrm{g} / \mathrm{l}$ (median 0.60 ) for prostate-specific antigen- $\alpha_{1}$-antichymotrypsin complex.

The reference ranges ( $95 \%$ confidence limits) were established for $\alpha_{1}$-antichymotrypsin in 80 patients, male and female, attending outpatient clinics, who were free from bacterial or viral infection and malignant disease. The $95 \%$ confidence limits for $\alpha_{1}$-antichymotrypsin were $0.27-0.61 \mathrm{~g} / 1$ (median 0.38 ). There was no difference between $\alpha_{1}$-antichymotrypsin in males and females ( $p>0.75$ ).

There was a positive correlation between serum prostate-specific antigen and prostate-specific antigen- $\alpha_{1}$ antichymotrypsin complex in the reference group ( $r=0.63, p<0.01$, slope 0.25 , intercept 0.27 ) and no difference between serum and plasma values. There was a close correlation between prostate-specific antigen and prostate-specific antigen- $\alpha_{1}$-antichymotrypsin complex over the whole concentration range $\left(0-410 \mu \mathrm{g} / \mathrm{l} \alpha_{1}\right.$-antichymotrypsin; $0-270 \mu \mathrm{g} / 1$ prostate-specific antigen- $\alpha_{1}$-antichymotrypsin complex) $(\mathrm{r}=0.85, \mathrm{p}<0.01$, slope 0.57 , intercept -0.92$)$.

The correlation between $\alpha_{1}$-antichymotrypsin in serum and plasma was excellent $(r=1.00$, slope $=0.998$, intercept $=0.03 \mathrm{~g} / \mathrm{l})$, so that plasma or serum samples could be used for all three assays. In contrast to other studies (14), prostate-specific antigen was present at detectable levels in serum from females. This is not surprising, since prostate-specific antigen has been detected histochemically in urethral glands from both sexes (15).

\section{Assay precision data}

Table 2 shows the basic quality control data for all 3 assays. The intra-assay precision was represented by a compound precision profile, the inter-assay precision by conventional means, i.e. from the measurement of control sera in consecutive assays.

Specificity of the prostate-specific antigen$\alpha_{1}$-antichymotrypsin complex assay

Levels of up to $200 \mu \mathrm{g} / 1$ purified prostate-specific antigen measured in the prostate-specific antigen- $\alpha_{1}-$ antichymotrypsin complex assay gave values less than the first standard $(0.15 \mu \mathrm{g} / \mathrm{l})$, showing the assay to be specific for prostate-specific antigen- $\alpha_{1}$-antichymotrypsin complexes. 
Neither prostate-specific antigen- $\alpha_{1}$ antitrypsin nor prostate-specific antigen- $\alpha_{2}$ macroglobulin complexes were detectable in serum or plasma when measured with sandwich assays, showing that prostate-specific antigen forms specific complexes with $\alpha_{1}$-antichymotrypsin (8) but most probably not with other antiproteases. Attempts at complexing $\alpha_{1}$-antichymotrypsin, in the form of fresh plasma, with purified prostatespecific antigen $\left(M_{\mathrm{r}} 30000\right)$ did not result in complexes being formed in vitro.

This is in contrast to purified neutrophil elastase, which readily forms complexes with $\alpha_{1}$-antiproteinase and $\alpha_{2}$-macroglobulin present in fresh plasma.

\section{Experimental groups}

Sex-related differences in concentrations of prostatespecific antigen and prostate-specific antigen- $\alpha_{1}$-antichymotrypsin complex in healthy subjects

The levels of prostate-specific antigen were, as to be expected, higher in healthy men than in healthy women (men-median $1.27 \mu \mathrm{g} / \mathrm{l}$, women-median 0.16 $\mu \mathrm{g} / 1, \mathrm{p}<0.01$ Mann Whitney U-test). The levels of prostate-specific antigen- $\alpha_{1}$-antichymotrypsin complex were also higher in healthy men than in healthy women (men-median $1.18 \mu \mathrm{g} / \mathrm{l}$, women-median 0.78 $\mu \mathrm{g} / \mathrm{l})$, although this difference was not significant.

\section{Patients with prostatic cancer and benign hyperplasia or hypertrophy of the prostate}

Assays employing prostate-specific antigen and prostate-specific antigen- $\alpha_{1}$-antichymotrypsin complex were compared for their ability to differentiate between benign and malignant prostate disease.

Twenty patients with clinically confirmed prostate carcinomata with $(12 / 20)$ and without $(8 / 20)$ metastasis were compared with 15 patients presenting with benign prostatic hypertrophy or hyperplasia $(9 / 15)$ or prostatitis $(6 / 15)$.

Whereas all carcinoma/adenoma patients had pathologically elevated concentrations of prostate-specific antigen, normal prostate-specific antigen- $\alpha_{1}$-antichymotrypsin complex levels were seen in three cases of prostate carcinoma. In the benign prostatic hyperplasia group $6 / 9$ presented with elevated prostate-specific antigen and $5 / 9$ with elevated prostate-specific antigen- $\alpha_{1}$-antichymotrypsin complex. In the patients with prostatitis $4 / 6$ presented with elevated prostatespecific antigen and $3 / 6$ with elevated prostate-specific antigen- $\alpha_{1}$-antichymotrypsin complex. The results are summarised in table $3 a-3 c$.
Tab. 3. Values obtained from patients with prostatic disease

\begin{tabular}{lll}
\hline Patient No. & $\begin{array}{l}\text { Prostate-specific } \\
\text { antigen- } \alpha_{1} \text {-anti- } \\
\text { chymotrypsin } \\
\text { complex } \\
(\mu \mathrm{g} / 1)\end{array}$ & $\begin{array}{l}\text { Prostate-specific } \\
\text { antigen }\end{array}$ \\
& $(\mu \mathrm{g} / 1)$ \\
\hline
\end{tabular}

a) Prostatic adenocarcinomata with 'metastasis

$\begin{array}{rcc}1 \text { pre-op } & 46.4 & 31.0 \\ 12 \text { months post-op } & 72.5 & 54.8 \\ 2 & 54.0 & 22.0 \\ 3 & 410 & 270 \\ 4 & 90.0 & 85.0 \\ 5 & 25.7 & 11.3 \\ 6 \text { pre-op } & 10.7 & 5.83 \\ \text { post-op } & 6.81 & 3.06 \\ 7 & 137 & 98.0 \\ 8 & 82.0 & 40.2 \\ 9 & 22.1 & 7.70 \\ 10 & 8.56 & 0.78 \\ 11 & 30.0 & 3.72 \\ 12 & 107 & 1.24\end{array}$

b) Prostate adenocarcinomata without metastasis

$\begin{array}{lcc}13 \text { pre-op } & 12.3 & 6.02 \\ \text { post-op } & 6.04 & 1.16 \\ 14 & 16.6 & 5.60 \\ 15 & 6.50 & 2.24 \\ 16 & 9.42 & 4.53 \\ 17 & 8.46 & 4.02 \\ 18 & 17.6 & 5.66 \\ 19 & 14.5 & 5.01 \\ 20 & 9.55 & 2.74\end{array}$

c) Benign prostate hyperplasia and prostatitis $(P)$

\begin{tabular}{|c|c|c|c|}
\hline $21 \mathrm{P}$ & 1.72 & & 1.26 \\
\hline $22 \mathrm{P}$ before therapy & 2.45 & & 0.59 \\
\hline control & 2.37 & & 0.69 \\
\hline $23 n$ & 5.32 & & 1.96 \\
\hline $24 \mathrm{P}$ before therapy & 10.5 . & $\therefore \quad-$ & 4.32 \\
\hline control & 9.97 & & 2.30 \\
\hline $25 \mathrm{P}$ & 7.36 & & 3.85 \\
\hline $26 \mathrm{P}$ & 11.4 & & 2.14 \\
\hline 27 & 4.25 & & 3.22 \\
\hline 28 & 5.87 & & 3.36 \\
\hline 29 & 10.1 & & 2.86 \\
\hline 30 & 8.87 & & 2.15 \\
\hline 31 & 0.32 & & 0.22 \\
\hline 32 & 4.69 & & 0.61 \\
\hline 33 & 13.0 & & 3.44 \\
\hline 34 & 6.30 & & 1.25 \\
\hline 35 & 7.05 & & 1.68 \\
\hline
\end{tabular}

Patients with other urological disorders

30 male patients attending the urology clinic for nephrolithiasis $(n=20)$ and urinary tract infections $(n=10)$ were taken as a control group. The range of prostate-specific antigen concentrations was $0.27-$ $4.21 \mu \mathrm{g} / \mathrm{l}$ (median $1.73 \mu \mathrm{g} / \mathrm{l}$ ) and for prostate-specific antigen- $\alpha_{1}$-antichymotrypsin complex $0.16-2.87 \mu \mathrm{g} / 1$ (median $0.66 \mu \mathrm{g} / \mathrm{l}$ ). The values correlated with each other in a similar way to those from healthy individuals $(r=0.53, p<0.005)$. Two patients had elevated results, one in each assay. 


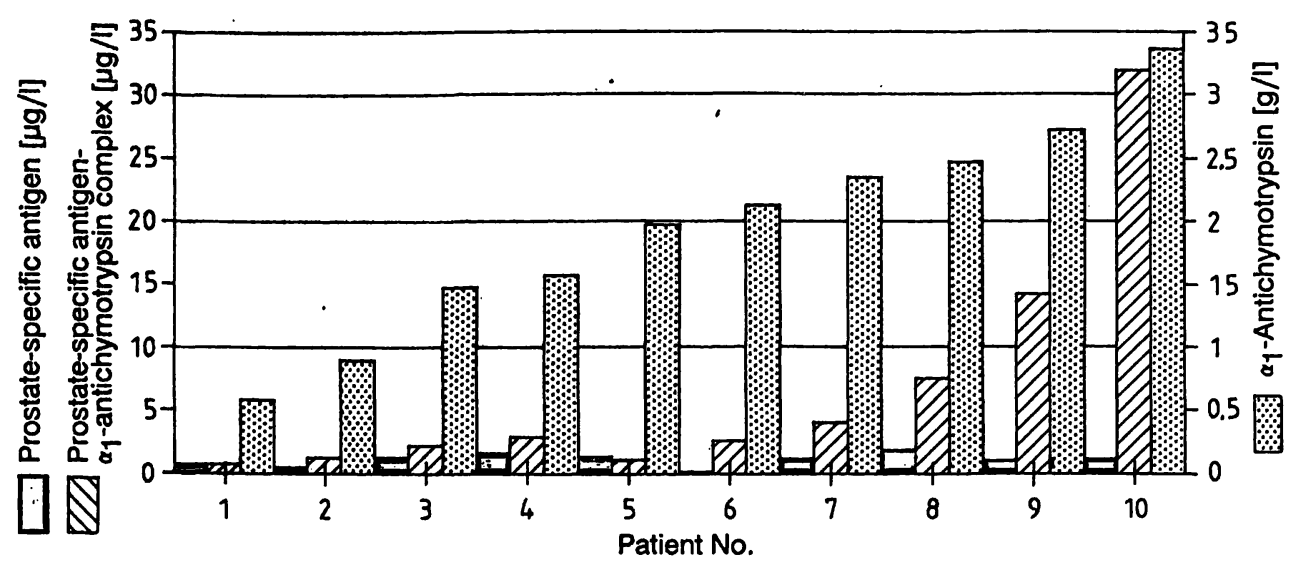

Fig. 1. Ten selected cases showing the effects of increasing $\alpha_{1}$-antichymotrypsin concentrations in serum on the results obtained in the prostate-specific antigen- $\alpha_{1}$-antichymotrypsin complex assay. The concentrations of prostate-specific antigen in these samples is also given.

Bacterial and viral infections - Effects on measured concentrations of prostate-specific antigen- $\alpha_{1}$-antichymotrypsin complex

There was a correlation between $\alpha_{1}$-antichymotrypsin levels and measured prostate-specific antigen- $\alpha_{1}$-antichymotrypsin complex levels in patients with bacterial and or viral infection, but without prostate disease, showing that high $\alpha_{1}$-antichymotrypsin levels may lead to an increase in measured prostate-specific antigen- $\alpha_{1}$-antichymotrypsin complex concentrations in such patients. Figure 1 shows the relationship between prostate-specific antigen, prostate-specific antigen- $\alpha_{1}$-antichymotrypsin complex and elevated $\alpha_{1}$ antichymotrypsin based on 10 selected patients.

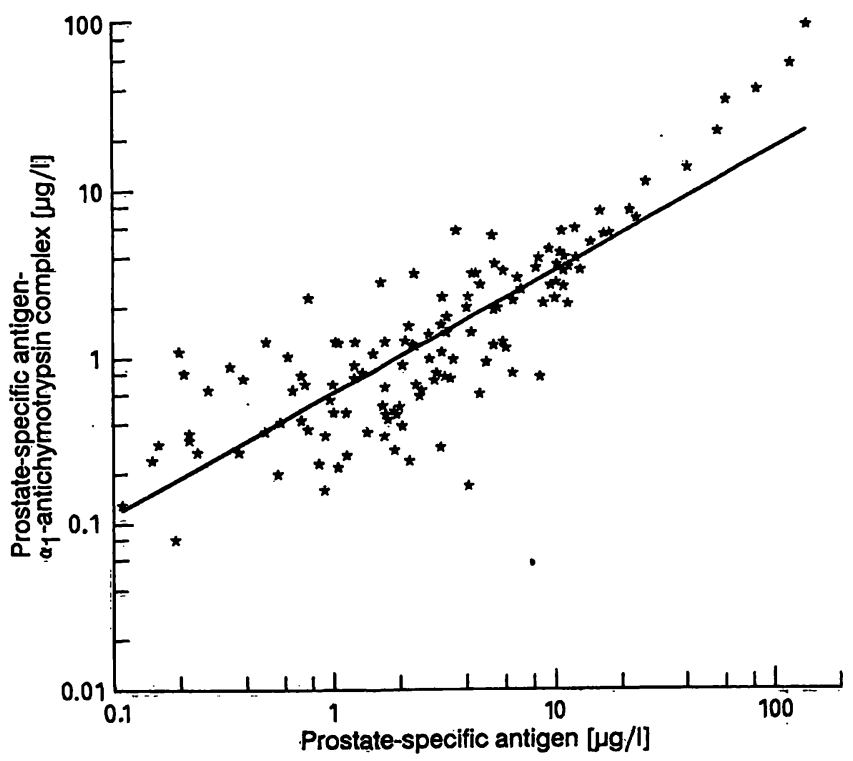

Fig. 2. Correlation between prostate-specific antigen and pros= tate-specific antigen- $\alpha_{1}$-antichymotrypsin complex in 131 subjects with normal $\alpha_{1}$-antichymotrypsin serum concentrations.

The correlation coefficient was 0.829 and $p<0.001$. The regression line equation was $(\log y)=0.74(\log x)$ -0.21 .
The correlation between prostate-specific antigen and prostate-specific antigen- $\alpha_{1}$-antichymotrypsin complex is markedly better ( $r=0.85$ compared with $\mathrm{r}=0.57$ ) when patients with high $\alpha_{1}$-antichymotrypsin are excluded (fig. 2).

Values of $\alpha_{1}$-antichymotrypsin above $2 \mathrm{~g} / \mathrm{l}$ (more than 3 times the upper limit of the reference range described above) are likely to give rise to pathological values for prostate-specific antigen- $\alpha_{1}$-antichymotrypsin complex. This means that in patients with bacterial infections, care must be taken in interpreting prostatespecific antigen- $\alpha_{1}$-antichymotrypsin complex levels. In patients with elevated prostate-specific antigen levels and normal or slightly elevated $\alpha_{1}$-antichymotrypsin the correlation between prostate-specific antigen and prostate-specific antigen- $\alpha_{1}$-antichymotrypsin complex is excellent. The slope of the regression line is not unity, due to the materials used for calibration. Purified prostate-specific antigen $\left(M_{\mathrm{r}} 30000\right)$ is used for calibrating the commercial kits, whereas naturallyoccurring prostate-specific antigen- $\alpha_{1}$-antichymotrypsin complexes $\left(M_{\mathrm{r}} 100000\right)$ were prevalent in the serum used for calibrating the sandwich assay for prostate-specific antigen- $\alpha_{1}$-antichymotrypsin complex.

Extra wash steps reduce carry-over considerably without significantly reducing the specific binding. In a study on 63 urological patients, without prostatic cancer and with normal and elevated $\alpha_{1}$-antichymotrypsin levels, all were assayed for prostate-specific antigen, as well as for prostate-specific antigen- $\alpha_{1}$ antichymotrypsin complex with $2 \times 5 \mathrm{ml}$ wash steps (asssay method 1) and $4 \times 5 \mathrm{ml}$ wash steps (assay method 2).

The results are shown in table 4. Prostate-specific antigen- $\alpha_{1}$-antichymotrypsin complex levels were significantly lower in assay method 2. Patients with 
Tab. 4. Effect of washing on the unspecific adsorption of $\alpha_{1}$ antichymotrypsin in the prostate-specific antigen- $\alpha_{1-}$ antichymotrypsin complex assay on 63 samples with prostate-specific antigen levels less than $6 \mu \mathrm{g} / \mathrm{l}$.

Range of prostate-specific antigen $0.19-5.84 \mu \mathrm{g} / \mathrm{l}$ (median 1.73 $\mu \mathrm{g} / \mathrm{l})$.

Range of $\alpha_{1}$-antichymotrypsin $0.22-2.01 \mathrm{~g} / 1$ (median $0.52 \mathrm{~g} / \mathrm{l}$ ).

Assay method 1 - with $2 \times 5 \mathrm{ml}$ wash steps between incubations.

Range of prostate-specific antigen- $\alpha_{1}$-antichymotrypsin complex $0.14-2.87 \mathrm{~g} / 1$ (median $0.68 \mathrm{~g} / \mathrm{l}$ ).

Assay method 2 - with $4 \times 5 \mathrm{ml}$ wash steps between incubations.

Range of prostate-specific antigen- $\alpha_{1}$-antichymotrypsin complex $0.08-1.64 \mathrm{~g} / \mathrm{l}$ (median $0.44 \mu \mathrm{g} / \mathrm{l}$ ).

Wilcoxon signed rank test assay method 1 vs assay method 2 $\mathrm{p}<0.001$.

Linear regression data prostate-specific antigen vs prostatespecific antigen- $\alpha_{1}$-antichymotrypsin complex

Assay method 1 - r (Spearman) 0.507 p $<0.005$

Assay method 2 - r (Spearman) 0.483 p $<0.005$

elevated $\alpha_{1}$-antichymotrypsin showed much reduced non-specific binding after increased washing (see figure 3 - selected sera).

Prostate-specific antigen, prostate-specific antigen- $\alpha_{I^{-}}$ antichymotrypsin complex levels in other groups with non-prostatic disease

Four from 6 females with pulmonary infections had falsely elevated prostate-specific antigen- $\alpha_{1}$-antichymotrypsin complex due to interference from excessively high $\alpha_{1}$-antichymotrypsin concentrations in their serum. These four patients are number $7,8,9$ and 10 in figure 1.
Reports have been published of antibodies to prostate-specific antigen, which may give rise to measurable prostate-specific antigen concentrations in women (11). In the present investigation, prostatespecific antigen levels were therefore also studied in sera from women, as part of a general study of "problem patients" (with regard to laboratory tests). A 46year old woman was found to have "prostate-specific antigen-antibodies" which gave rise to elevated "prostate-specific antigen" levels in the prostate-specific antigen radioimmunoassay. In this case, a prostatespecific antigen value of $5.2 \mu \mathrm{g} / 1$ (prostate-specific antigen- $\alpha_{1}$-antichymotrypsin complex $0.20 \mu \mathrm{g} / \mathrm{l}$ ) was measured. The serum had a high unspecific binding of labelled prostate-specific antigen after polyethylene glycol precipitation, which indicated the presence of antibodies to prostate-specific antigen. A similar case was seen in a 54 year old man with nephritis who had "prostate-specific antigen-levels" of $21.8 \mu \mathrm{g} / \mathrm{l}$, prostate-specific antigen- $\alpha_{1}$-antichymotrypsin complex levels of 0.27 and $\alpha_{1}$-antichymotrypsin of $0.58 \mathrm{~g} / \mathrm{l}$.

Sera from a group of renal insufficiency patients, as well as those with proven lung carcinoma, were also checked for "prostate-specific antigen" and "prostatespecific antigen- $\alpha_{1}$-antichymotrypsin complex".

In one case of renal insufficiency, a prostate-specific antigen level of $5.3 \mu \mathrm{g} / \mathrm{l}$ was measured. Prostate-specific antigen- $\alpha_{1}$-antichymotrypsin complex was normal $(1.20 \mu \mathrm{g} / \mathrm{l})$. A 90 year old man with a phimosis had elevated prostate-specific antigen (pre-op. 10.1 $\mu \mathrm{g} / \mathrm{l}$, post-op. $11.4 \mu \mathrm{g} / \mathrm{l}$ ) as well as prostate-specific antigen- $\alpha_{1}$-antichymotrypsin complex (pre-op. 2.86 $\mu \mathrm{g} / \mathrm{l}$, post-op. $2.14 \mu \mathrm{g} / \mathrm{l})$. In one case of prostatic cancer treated by bilateral orchidectomy, prostatespecific antigen levels were $0.27 \mu \mathrm{g} / 1$ and prostatespecific antigen- $\alpha_{1}$-antichymotrypsin complex 0.09

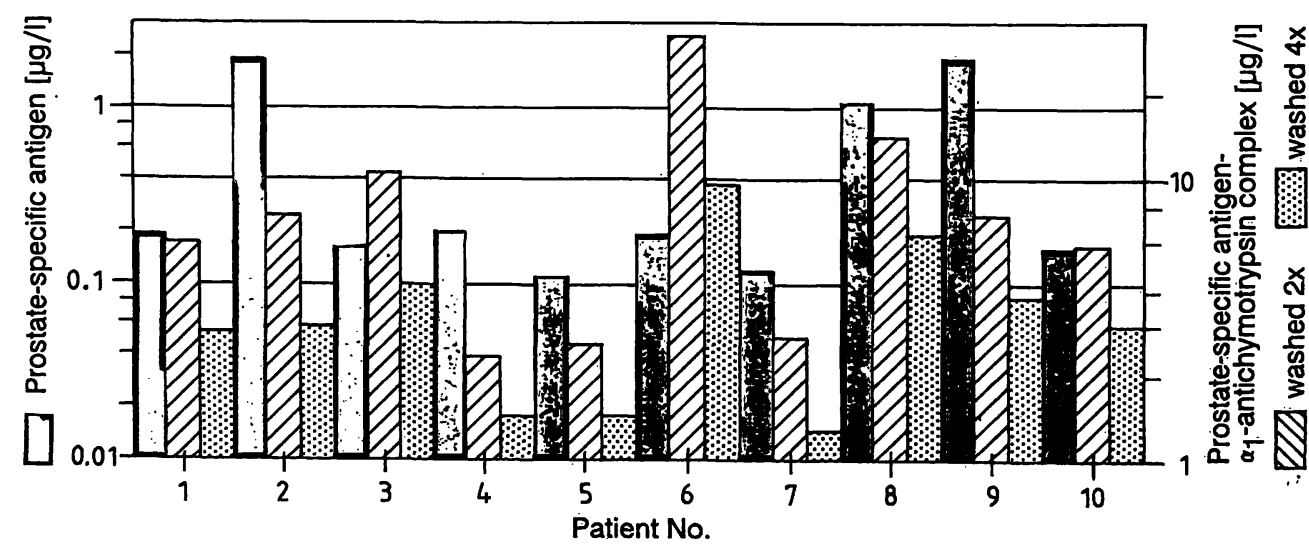

Fig. 3. Selected patients with normal serum prostate-specific antigen levels and with grossly elevated $\alpha_{1}$-antichymotrypsin ( $>2$ g/l) in serum. The effects on "prostate-specific antigen- $\alpha_{1}$-antichymotrypsin complex levels" by washing with $2 \times 5 \mathrm{ml}$ and $4 \times 5 \mathrm{ml}$ between incubation steps are shown. 
$\mu \mathrm{g} / \mathrm{l}$ six months after operation. Nephrolithiasis patients $(n=20)$ and patients with urinary tract infections $(n=10)$ had normal levels of prostate-specific antigen, prostate-specific antigen- $\alpha_{1}$-antichymotrypsin complex and $\alpha_{1}$-antichymotrypsin. One woman with lung cancer had elevated levels of prostate-specific antigen and prostate-specific antigen- $\alpha_{1}$-antichymotrypsin.

\section{Discussion}

Although the introduction of the assay for prostatespecific antigen has led to a better discrimination between patients with prostatic cancer and those with inflammation of the prostate, there is still some overlap between both groups, which reduces the clinical specificity and sensitivity of the test. As it has been shown that prostate-specific antigen normally circulates as a complex with $\alpha_{1}$-antichymotrypsin (8), an assay was developed to see whether the measurement of prostate-specific antigen- $\alpha_{1}$-antichymotrypsin complex would improve the diagnostic value of the prostate-specific antigen determination. This would be analogous to the measurement of elastase- $\alpha_{1}$-antitryp$\sin (10)$.

The results show that the assay for prostate-specific antigen- $\alpha_{1}$-antichymotrypsin complex is much quicker than that for prostate-specific antigen, as well as needing a smaller sample volume. Difficulties arise, however, due to non-specific adsorption of $\alpha_{1}$-antichymotrypsin to the solid phase and to the production of prostate-specific antigen not coupled to $\alpha_{1}$-antichymotrypsin, as seen in three patients with metastasis. Increasing the number of wash steps $(4 \times 5 \mathrm{ml})$ between each incubation reduces the unspecific adsorption effects due to $\alpha_{1}$-antichymotrypsin, although it does not completely alleviate the problem. Although falsely elevated results do not become apparent until $\alpha_{1}$-antichymotrypsin levels exceed three times the upper limit of the reference range for healthy volunteers, such levels can occur in extreme cases of bacterial infection, as seen in cases of pulmonary sepsis (see fig. 1), where the female patients with "elevated prostate-specific antigen- $\alpha_{1}$-antichymotrypsin complex" were all from the pulmonary unit.

The advantages of the prostate-specific antigen- $\alpha_{1}$ antichymotrypsin complex assay are its short incubation times and its ability to give "correct answers" in the rare cases of patients with "anti-prostate-specific antigen-like activity" (11).

As both $M_{\mathrm{r}} 30000$ and $M_{\mathrm{r}} 100000$ "prostate-specific antigen" (free and complexed) have been seen in electrophoresis of seminal fluid (8), the ratio of prostate- specific antigen to prostate-specific antigen- $\alpha_{1}$-antichymotrypsin complex may be a useful clinical indicator, but this involves the performance of an additional laboratory test.

Purified prostate-specific antigen $\left(M_{\mathrm{r}} 30000\right)(1)$ did not complex with $\alpha_{1}$-antichymotrypsin in plasma, showing either that the active formation of complexes normally takes place in the prostate, or that the prostate-specific antigen had lost its ability to combine with $\alpha_{1}$-antichymotrypsin during purification.

There were interesting cases where a woman with "prostate-specific antigen-like immunoreactivity" had an elevated unspecific binding of prostate-specific antigen tracer if the serum was precipitated with polyethylene glycol (end concentration $150 \mathrm{~g} / \mathrm{l}$ ), which pointed to the presence of antibodies to prostatespecific antigen. One man with nephritis also had antibodies to prostate-specific antigen. Three cases of metastasing prostate carcinoma had discrepant values for prostate-specific antigen and prostate-specific antigen- $\alpha_{1}$-antichymotrypsin complex (prostate-specific antigen 8.56, 30.0 and $107 \mu \mathrm{g} / \mathrm{l}$, prostate-specific antigen- $\alpha_{1}$-antichymotrypsin complex $0.78,3.72$ and $1.24 \mu \mathrm{g} / \mathrm{l})($ Cases 10-12 - tab. 3a). The latter cases point to the production of an abnormal neoplastic prostate-specific antigen which was incapable of binding to $\alpha_{1}$-antichymotrypsin in the normal way, as $\alpha_{1}$ antichymotrypsin was present in serum in normal concentrations.

To conclude, both assays can be used in the diagnosis and follow up of prostatic cancer, the results from the prostate-specific antigen- $\alpha_{1}$-antichymotrypsin complex assay being available on the same day, using a sample of only $110 \mu \mathrm{l}$ for a duplicate determination. This is offset by the fact that grossly elevated levels of $\alpha_{1}$-antichymotrypsin may give rise to falsely elevated prostate-specific antigen- $\alpha_{1}$-antichymotrypsin complex levels in serum or plasma, which can be reduced but not fully excluded by increasing the number of wash steps.

Further experimentation is needed to examine whether the prostate-specific antigen- $\alpha_{1}$-antichymotrypsin complex assay can be used in post-op. followup and early diagnosis of metastases. Whether the ratio, free : complexed prostate-specific antigen, may act as an indicator of metastatic growth (supported by cases $10-12$, tab. 3a) must also be investigated further.

In the light of the present results, prostate-specific antigen- $\alpha_{1}$-antichymotrypsin complex alone is not expected to be more specific than prostate-specific antigen or prostate acid-phosphatase as a screening parameter. 


\section{Acknowledgements}

The authors would like to thank Frau Betina Polke for typing the manuscript and Herr Kai Ramming for writing the computer programmes used in the statistical analysis.
The assistance of the staff of the urological outpatient clinic is acknowledged, without whose help the collection of samples would have been impossible.

\section{References}

1. Wang, M. C., Valensuela, L. A., Murphy, G. P. \& Chu, T. M. (1979) Purification of a human prostate specific antigen. Invest. Urol. 17, 159-163.

2. Sensabaugh, G. F. (1978) Isolation and characterisation of a semen-specific protein from human seminal plasma: a potential new marker for semen identification. J. Forensic Sci. 23, 106-115.

3. Filella, X., Molina, R., Jo, J., Umbert, B., Bedini, J. L. \& Ballesta, A. M. (1990) Clinical usefulness of prostate-specific antigen and prostatic acid phosphatase in patients with prostatic cancer. Tumour Biol. 11, 289-294.

4. Haukaas, S., Skaarland, E., Halvorsen, O. J., Stensland, E. \& Farstad, M. (1990) Prostataspesifikt antigen. En ny biologisk serummarkor ved adenokarsinom i prostata. Tidsskr. Nor. Laegeforen. 110, 2990-2993.

5. Jurincic, C. D., Pixberg, H. U., Grasser, A. \& Klippel, K. F. (1990) Prostate-specific antigen in prostatic carcinoma. Urol. Int. 45, 153-159.

6. Drago, J. R., Badalamont, R. A., Wientjes, M. G., Smith, J. J., Nesbitt, J. A. \& York, J. P. (1989) Relative value of prostate-specific antigen and prostatic acid phosphatase in diagnosis and management of adenocarcinoma of prostate. Ohio State University experience. Urology 34, 187-192.

7. Poipell, C. S., Fielding, A. M., Rosser, K., Ames, A. C. \& Vaughton, K. C. (1989) Prostate-specific antigen - a screening test for cancer? Brit. J. Urol. 64, 504-506.

8. Stenman, U. H., Alfthan, H. \& Turpeinen, U. (1991) Method dependence of interpretation of immunoassay results. Scand. J. Clin. Lab. Invest. 51, Suppl. 205, 86-94.

9. Lee, C., Keafer, M., Zhau, Z. W., Kroes, R., Berg, L., Liu, X. X. \& Sensibar, J. (1989) Demonstration of the role of prostate-specific antigen in semen liquefaction by two dimensional electrophoresis. J. Androl. 10, 432-438.
10. Sakurabayaski, I., Itoh, H., Ishii, S., Iimura, Y., Homma S., Shimanuki, K. \& Kawai, T. (1985) Clinical evaluation of a new method for granulocyte elastase. In: Elastase a new marker for inflammatory diseases (Froeschle, M. C., Goeth, W. A., eds.) GIT-Verlag, Darmstadt, pp. 27-38.

11. Graves, H. C. B., Wehner, N. \& Stamey, T. A. (1990) Comparison of a polyclonal and monoclonal immunoassay for PSA: Need for an international antigen standard. J. Urol. 144, 1516-1522.

12. Schroeder, H. R. \& Yeager, F. M. (1978) Chemiluminescence yields and detection limits of some isoluminol derivatives in various oxidation systems. Anal. Chem. 50,11141120.

13. Wood, W. G. \& Mißler, U. (1990) Setting up and optimising solid-phase luminescence immunoassays using 1,2-diacyl aryl hydrazides as labels. In: Luminescence Immunoassay and Molecular Applications (van Dykè, K., van Dyke, R., eds.) CRC Press, Boca Raton, Ann Arbor, Boston, Chapter 9, pp. 142-156.

14. Zundel, D., Jarry, H., Kestler, D., Holzapfel, G., Barthels, H., Scheit, K. H. \& Wuttke, W. (1990) Development and evaluation of an enzyme-linked immunoassay for the prostate-specific antigen utilising two monoclonal antibodies. Urol. Res. 18, 327-330.

15. Kamoshida, S. \& Tsutsami, Y. (1990) Extraprostatic localisation of acid phosphatase and prostate-specific antigen: distribution in cloacogenic glandular epithelium and sexdependent expression in human anal gland. Hum. Pathol. $21,1108-1111$.

Prof. W. G. Wood

Klinische Laboratorien

Klinik für Innere Medizin

ZK 3.4.10

Ratzeburger Allee 160

W-2400 Lübeck 1

Bundesrepublik Deutschland 